\title{
ANALYSIS AND IMPROVEMENT OF PRODUCTION EFFICIENCY IN A CONSTRUCTION MACHINE ASSEMBLY LINE.
}

\author{
Alidiane Xavier \\ Federal Institute of São Paulo, Brazil \\ E-mail:alidianexavier@yahoo.com.br \\ Murilo de Melo Gonzalez \\ Federal Institute of São Paulo, Brazil \\ E-mail:murilo_t8@hotmail.com \\ Submission: 31/03/2016 \\ Accept: 31/03/2016
}

\section{ABSTRACT}

The increased competitiveness in the market encourages the ongoing development of systems and production processes. The aim is to increase production efficiency to production costs and waste be reduced to the extreme, allowing an increased product competitiveness. The objective of this study was to analyze the overall results of implementing a Kaizen philosophy in an automaker of construction machinery, using the methodology of action research, which will be studied in situ the macro production process from receipt of parts into the end of the assembly line, prioritizing the analysis time of shipping and handling. The results show that the continuous improvement activities directly impact the elimination of waste from the assembly process, mainly related to shipping and handling, improving production efficiency by $30 \%$ in the studied processes.

Keywords: Internal Logistics, Picking, Assembly Line, Productive Efficiency. 


\section{INTRODUCTION}

The boost of the domestic market on the past years, leveraged by government programs and major sport events, increased the interest in investments of foreign countries in Brazil. In the construction machinery market, the main investments are from Asian origin. Led by China in terms of investment (Table 1), which defines Brazil as a strategic partner, as it has 1.4 billion inhabitants and US $\$ 2.4$ trillion of reserves, thus having much need for food, oil, iron ore, energy, etc. (Estado de São Paulo - February 11th, 2011).

Table 1: Recently Installed in Brazil

\begin{tabular}{|l|l|c|}
\hline \multicolumn{3}{|c|}{ Recently installed in Brazil } \\
\hline \multicolumn{1}{|c|}{ Companies } & \multicolumn{1}{c|}{ Investment } & Origin \\
\hline San Heavy Industries & U\$ 100 Millions & China \\
\hline Liu Gong Machinery & U\$ 120 Millions & China \\
\hline XCMG & U\$ 1 Billion & China \\
\hline Hyundai & U\$ 150 Millions & South Korea \\
\hline Doosan & U\$ 35 Millions & South Korea \\
\hline
\end{tabular}

Source: Estado de São Paulo (February 11th, 2011)

On the other hand, there was also stimulating competitiveness, since Chinese companies have segmentation strategy of low costs. The need to reduce manufacturing costs, to increase profitability makes companies seek, increasingly, lean production systems. However, the decision of which method to use and whether it will meet the needs is still a paradigm for many companies.

The decision-making process appears as an unexplored factor in the work of spreading the lean production model. Toyota is recognized as the worldwide pioneer in this method, by creating a focused production system for the continuous improvement of productivity indicators and quality. The companies using lean manufacturing approach, in general, have a competitive advantage over those using traditional approaches, as it has been realized by the industry and also by the academy, not only in developed countries but also in emerging countries (TORRES JUNIOR, 2010 ).

To obtain a progressive removal of losses, it takes a close relationship between customer and suppliers, whether external or internal, meaning that the focus of a company is to become lean and healthy supply chain, through a win winrelationship with everyone involved. 
DOI: $10.14807 /$ ijmp.v7i5.453

The target company in this study is originated in Japan and has been in Brazil for more than 40 years as part of machinery section for Construction, Mining and Forestry. The objective of this study is to analyze the overall results of the kaizen philosophy implementation at in-house logistics in a construction machinery factory. Our target is the production efficiency and its influences with the process in order to answer the following research problem: "The application of kaizen system, in addition to the parts concentration and the representativeness analysis of travel in the picking contribute as tools for improving the efficiency of an assembly line?"

Eliminating the losses in the production process, it is expected to obtain gains in the flow of the studied assembly line, making it more efficient. The research methodology adopted in this study is action-research, which is a type of research with empirical basis, to solve a collective problem and that researchers are involved in a cooperative and participative way.

It is known that the methods and concepts used in this article can be used in any companies that have a production line with a big volume of control items. This work is structured as follow: The first session deals with the introduction and the context in which the company under study is inserted. The second section presents the theoretical basis of the topics discussed. The third section presents the proposed method for the study. The fourth section describes the results obtained after the implementation of activities. The conclusion of the research together with his closing statements is presented in the fifth section.

\section{THEORETICAL REFERENCE}

Among the many changes that have occurred in automakers over the years, most of them refer to the mass production system, which begins with the creation of the first mass production model named, by the American businessman Henry Ford, Fordism in 1914.

In the mid-70s, facing the need for flexibility production, there is a unique and new way of managing the work process: the Toyotism. There, the workers become multifunctional specialists. He raised the productivity of Japanese auto companies by eliminating losses and it is now considered a model adapted to flexible production system. Among its features are: the existence of a cooperative relationship between 
DOI: 10.14807/ijmp.v7i5.453

managers and workers, that is a horizontal administrative hierarchy; rigid quality control.

According to Pergher (2011), "The Toyota Production System (TPS) is one of contemporary approaches to widespread production engineering in the industrial context, which proposes improvements in processes, by eliminating the losses."

Shimokawa and Fujimoto (2011) bring the Toyota production system is based on two basic concepts: cost savings through the elimination of losses and the recognition of the Japanese diligence.

The Kaizen system is premised on continuous improvement and its philosophy is an important resource in the relentless pursuit of improvement in production and administrative processes, making them leaner and faster. Monteiro (2012) points out that "The Japanese word Kaizen means" continuous improvement "results from combining two words Kai and Zen, which means" change "and" better ", respectively".

Considered as the main cause of the Japanese success, the Kaizen has been spread to many countries. Companies around the world have used this management model in their processes, seeking to improve the quality of its products and services to meet customer needs, with reducing of time and operations cost, thus obtaining the desired profit. (MEDEIROS, 2012).

Peinado and Graeml (2012) cite the importance of the analysis, improvement and review of logistics processes of the organizations to serve their strategy even better. The competition for greater efficiency has led some companies to update and use new ways to conduct their business, having as one of its main objectives the seeking for improvements by developing new business models or even adopting intensive technology in improving processes, products and services.

Ramos (2014) brings the term lean production as a way to do more with less, in order to organize in the best way the production processes and build strong relationships with customers and suppliers, by using the pulled production system. In this system, production happens from the customer's request, making the raw material to be purchased as needed for production, avoiding stocking of finished product. In addition, Saurin and Ferreira (2008) classify it as a new industrial organization system, inspired by the Toyota Production System (TPS), which aims to 
DOI: 10.14807/ijmp.v7i5.453

eliminate any losses of the production system, enabling high quality services and products at the lowest cost possible and attending more effectively to customer needs.

In addition to this already mentioned, Hayes and Wheelwright in 1984, were the first to mention the term World Class Manufacturing, when describing developed capabilities by Japanese and German companies in competition for export markets. In 1986, Schonberger also cited such term in his book World Class Manufacturing taking the idea that adopting Just-in-Time and Total Quality practices, any company could reduce their lead time and become a World Class Manufacturing (CUTS, 2010). Thereafter, the two concepts have been adopted and expanded by several authors.

The main motivation of Lean Manufacturing methodology is to seek the time reducing between customer order and delivery through losses elimination. It promotes the identification of what adds value (and that does not add) from customer's perspective -The interconnection of necessary steps and goods production on the value flow, so that this proceed without interruptions, detours, returns, waits or losses - and the operation of this pulled demand flow (SILVA, et al., 2011).

The industries are going through a critical review of their own operating standards, regarding to its production planning and inventory control processes, so that it can have a production management even more detailed (DIAS, 2008).

Whenever a company seeks to reduce its operating costs and improve productivity, it carefully reconsiders their picking activity. The picking consists in collecting the right products, in the right quantity, to meet the needs expressed by customers. So it is from picking that begins in customer service and therefore this activity is aimed for much attention. The faster processes picking, the faster it is achieved to deliver to the customer (time); As more efficient the picking, the lower the cost to the customer; As more effective the picking, without mistakes, the greater is the quality of delivery (CARVALHO, 2010).

Tompkins (2010) observed (Figure 1) that travel time represented $50 \%$ of the picking activity. The travel time is a linear function of distance traveled in a pick-topart system, where the operator travels to the inventory. 


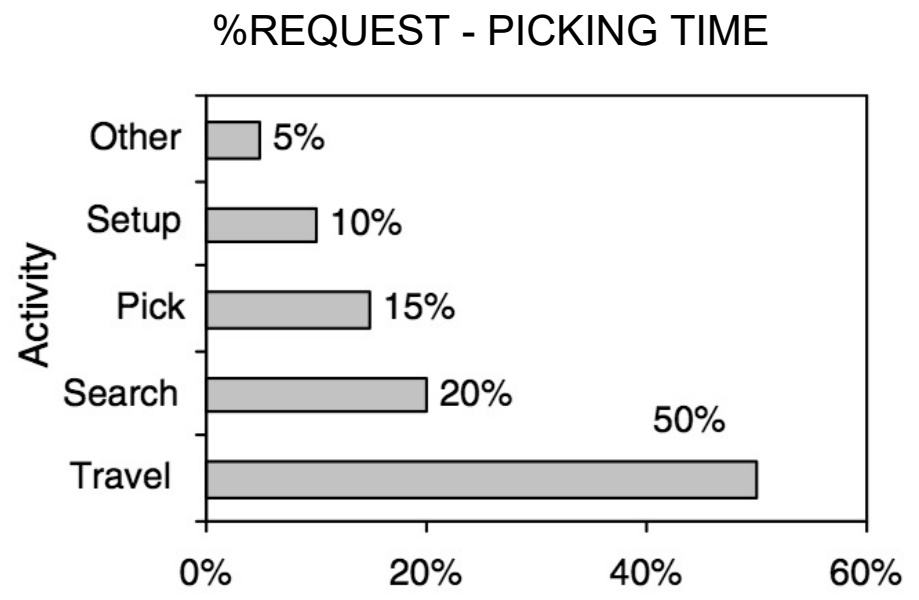

Figure 1: Typical Distribution picking time Source: Tompkins, 2010

Consequently, the travel distance is considered as one of the main objectives of the logistics processes optimization studies. Routing policies aim to minimize this distance in different contexts. (PUREZA; LAZARIN, 2010).

Pereira (2012) provides that "for routing being one of the most important and complex issues belonging to the distribution logistics, heuristics alternatives tothe problem are constantly presented ". Due to that, optimal methods have some disadvantages such as, depending on the layout it might not be an optimal solution to the routing problem, the optimum paths may seem illogical for operators that change their itinerary, an optimal method cannot take into account congestion in the paths, in which can be done with a heuristic model. Relating to that, according to Medeiros (2011) it has more approximate to the real results and require less computational effort, as compared to the exact methods.

Bartholdi and Hackman (2011) bring the travel time during the picking activity as a loss because it costs in terms of manpower and does not add value, generating the need for path analysis to be performed for all the activity in a production line, in order to achieve the aim of improving the process. In addition, Tompkins (2010) noted that such trips accounted for $50 \%$ of the time of picking activity, presenting another indication of the importance of the review of such parameter.

\section{RESEARCH METHOD}

The research methodology adopted in this study is action-research, in which according Thiollent (2011, p.14), can be defined as: 
DOI: $10.14807 /$ ijmp.v7i5.453

"... A kind of empirically based research that is designed and built in close association with an action or resolution of a collective problem and in which researchers and representative participants of the situation or problem are involved in a cooperative way or participative ."

According to the policies of the studied target company, including the terms of lean manufacturing quoted in this work will be deleted "World class manufacturing" and "Lean Manufacturing" because both derive from the same method and only have been adapted to other realities to be implemented.

Based on what Tompkins (2010) noted, in this work will be studied in loco the macro production process from parts receiving to their final use on the assembly line, prioritizing the handling and transportation time analysis, because it represents $50 \%$ from a picking process, relating that is the source that will bring the best results related to the improvement of process efficiency.

Before executing the activities, it will be measured the section production efficiency through a management software (Hyperion workspace) used in the studied company. This software makes the monthly measurement of employee's shifts time related to the production indication, which prevents any manipulation of the final results.

First of all, it will be made a chronological measurement of the times looking at the activities that do not add value to the process, by using a calibrated stopwatch. It was created a form containing the process segmentation, mainly interested in the transportation and handling times. It will be made Ishikawa diagram, also known as cause and effect diagram to find the possible causes of these problems, in order to gather similar processes as proposed in lean production, that is built in the assembly process and internal logistics parts preparation to reach the target sectionin thecorrect form, amount and time. To assist in methodology, it was created a $5 \mathrm{~W} 1 \mathrm{H}$ to define the activities, responsible people, and the purpose thereof. 
INDEPENDENT JOURNAL OF MANAGEMENT \& PRODUCTION (IJM\&P)

http://www.ijmp.jor.br

v. 7, n. 5, Special Edition IFLOG 2015

ISSN: 2236-269X

DOI: 10.14807/ijmp.v7i5.453

Table 2: $5 \mathrm{~W} 1 \mathrm{H}$ - Implementation of the Kaizen philosophy on the assembly line

\begin{tabular}{|c|c|c|c|c|c|}
\hline \multicolumn{6}{|c|}{ 5W1H } \\
\hline WHAT? & WHO? & WHEN? & WHERE? & WHY? & HOW? \\
\hline $\begin{array}{c}\text { Process } \\
\text { Cronoanalisys }\end{array}$ & technical team & Sep/13 & In house & $\begin{array}{c}\text { To identify not } \\
\text { necessary } \\
\text { activities }\end{array}$ & $\begin{array}{l}\text { Using } \\
\text { cronometer }\end{array}$ \\
\hline $\begin{array}{c}\text { Process } \\
\text { assestment } \\
\text { analisys }\end{array}$ & technical team & Sep/13 & In house & $\begin{array}{l}\text { To stimulate } \\
\text { assemblers } \\
\text { participation }\end{array}$ & $\begin{array}{c}\text { The assembler } \\
\text { will watch } \\
\text { video }\end{array}$ \\
\hline $\begin{array}{l}\text { Improvements } \\
\text { Sugestion } \\
\text { (Brainstorming) }\end{array}$ & All & Sep/13 & In house & $\begin{array}{l}\text { To eliminate } \\
\text { wastes }\end{array}$ & $\begin{array}{l}\text { Using Kaizen } \\
\text { Improvements }\end{array}$ \\
\hline Ideas Analisys & Technical team & Sep/13 & In house & $\begin{array}{l}\text { To select the } \\
\text { best idea }\end{array}$ & $\begin{array}{l}\text { Using theorical } \\
\text { references }\end{array}$ \\
\hline $\begin{array}{l}\text { Suppliers } \\
\text { selection }\end{array}$ & Purchase Team & Sep/13 & In house & $\begin{array}{l}\text { To select the } \\
\text { best price }\end{array}$ & Using 3 budget \\
\hline Prototype & Supplier & Sep/13 & Supplier Plant & $\begin{array}{l}\text { To check } \\
\text { problems }\end{array}$ & $\begin{array}{c}\text { Analisy pratical } \\
\text { test }\end{array}$ \\
\hline $\begin{array}{c}\text { Weaknesses } \\
\text { Analisys }\end{array}$ & All & Sep/13 & In house & $\begin{array}{l}\text { To correct for } \\
\text { the Serial } \\
\text { Production }\end{array}$ & $\begin{array}{l}\text { Using daily } \\
\text { meeting }\end{array}$ \\
\hline $\begin{array}{c}\text { Purch } \\
\text { documents }\end{array}$ & Purchase Team & Sep/13 & In house & $\begin{array}{l}\text { To possbility } \\
\text { Kaizen actities }\end{array}$ & Purchase Order \\
\hline $\begin{array}{l}\text { Logistic Layout } \\
\text { definition }\end{array}$ & Engineer team & Sep/13 & In house & $\begin{array}{l}\text { To reduce } \\
\text { movements }\end{array}$ & $\begin{array}{l}\text { Using the } \\
\text { scripting study }\end{array}$ \\
\hline Results analisys & All & Sep/13 & In house & $\begin{array}{c}\text { To check kaizen } \\
\text { activities }\end{array}$ & $\begin{array}{c}\text { To check the } \\
\text { new productive } \\
\text { efficience }\end{array}$ \\
\hline
\end{tabular}

As proposed by Ramos (2010), storage does not add value to the product, but contributes to the whole logistics system could comply with the proposed value. With this, it is aimed the gathering of stock in one place, improving parts control and reducing unnecessary handlings. To build a new domestic distribution center, called kitting, picking method will be defined as well as its routing.

It will be deployed S-Shape routing process, where the operators get into the corridors, in which there are parts in their respective locations to be separated as increasingly order of locations and comes out the opposite side necessarily. He goes on before finishing the kits separation. This strategy is the simplest, but based on what was done by Medeiros (2011), it will be the most appropriate method to be implemented by its convenience and for achieving an average solutions close to $5 \%$ of the optimal solution, which can confirm their usage in practice. 
DOI: 10.14807/ijmp.v7i5.453

During the unification of inventories, a survey will be raised based on the movements history in order to organize continuously and increasingly the parts that have higher inventory movements, and to position them to reduce handling during the picking process. The parts supply method will be studied with the participation of those involved in the process by exposing problems and improvement suggestions.

After implementing the presented methods, the results will be monitored in accordance to the section production efficiency measurement through management software (Hyperion workspace), where it will be seen within six months. It is known that the methods and concepts used in this article can be used in any companies that have a production line with a big volume of controlled items.

\section{RESEARCH}

\subsection{Manufacturing section Profile}

The assembly section, object of study, has a total area of $3.072 \mathrm{~m}^{2}$. It has rectangular shape with $96 \mathrm{~m}$ long and 32 meters wide. The assembly line itself is the continuous type and has a length of $75 \mathrm{~m}$ in which are produced 6 different models of construction machinery with about 30 different options.

The stock parts having a mass of over $500 \mathrm{~g}$ and / or bigger pieces than 50 $\mathrm{mm}$ in length are arranged next to the assembly line in shelves door pallets type, arranged as closest as possible to the work station where the parts are assembled (Figure 2).

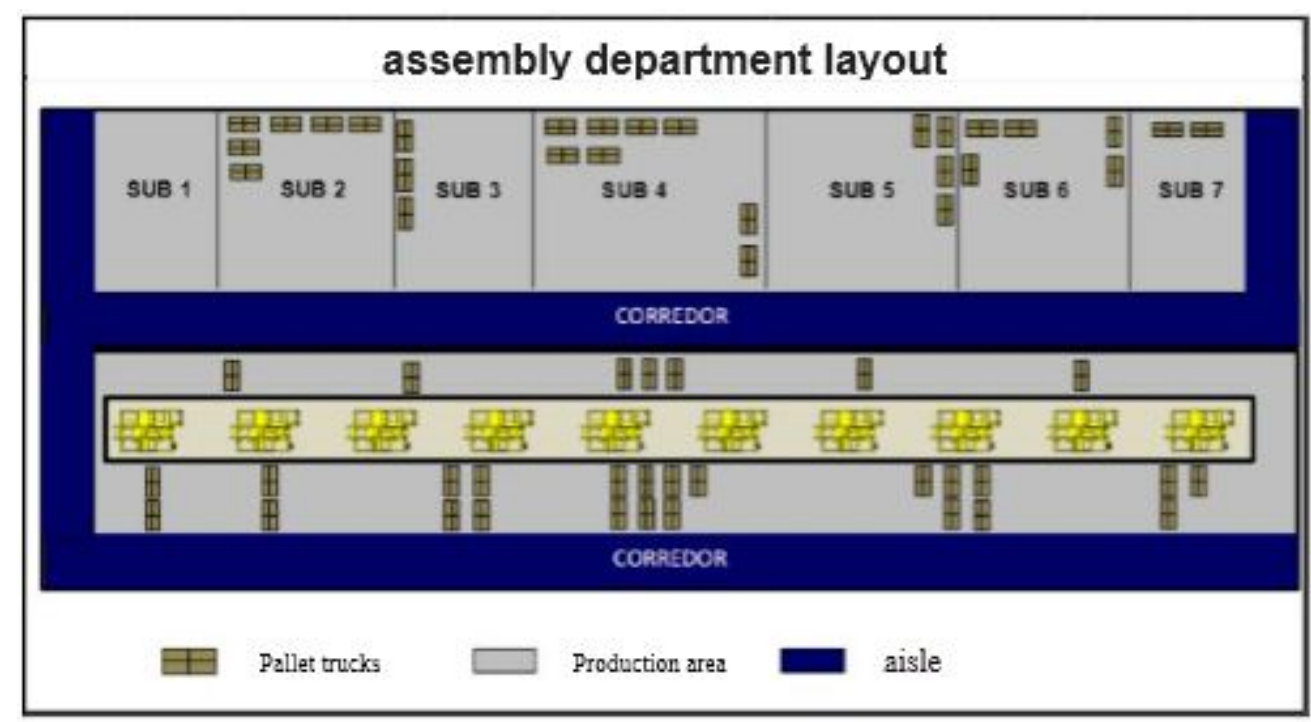

FIGURE 2: Assembly Industry Layout 
DOI: $10.14807 /$ ijmp.v7i5.453

The shelves are arranged in two categories: the first one called SA (Sub Assembly), making reference to the racks located on the sub assembly components which supply the main assembly line, and AL (assembly line), which references the shelves located on the Assembly Line.

Smaller parts, that weigh less than $500 \mathrm{~g}$ and have less than $50 \mathrm{~mm}$ are stocked in a warehouse with shelves rack Flow type called "Kitting" and subsequently supplied in plastic boxes per lot in supply cars. Those cars are removed by the assembler himself when occurs a change in the machine model to be produced.

The "Kitting" stock layout has a total area of $1536 \mathrm{~m}^{2}$. It is rectangular shape with $96 \mathrm{~m}$ long and $16 \mathrm{~m}$ wide. It has three aisles of parts separation, called K1, K2 and $\mathrm{K} 3$ with twenty-four shelves each. All shelves have the capacity to address 45 and 180 positions / box, which allows them to be stored 12,960 positions / box.

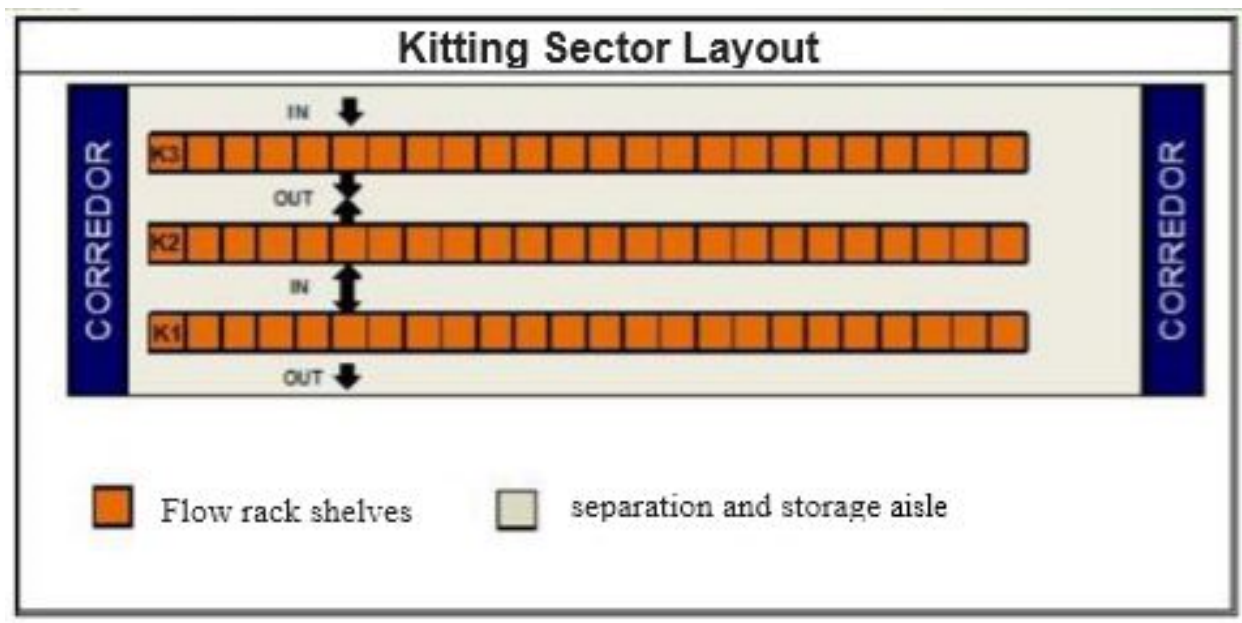

FIGURE 3: Kiting of Industry Layout

\subsection{Storage Policies}

When a new item arrives for the first time in the receiving dock, there is no defined location. Firstly, it will be classified according to the machine model to be used, and it will be stocked in "pallets on the floor" at the beginning of the assembly line. Then it should be allocated in Pallet holder closer to the place of use, or if the characteristics of the parts fit the Kitting section, it will be stored and then supplied as addressed.

The Picking system in assembly-line section is the pick-to-part type, that is a manual system where the operator travels to separate the items. The most critical 
DOI: $10.14807 /$ ijmp.v7i5.453

point in the case of the layout is shown in figure 3 , since in this case the "operator" is also the assembler.

There is not a particular routing policy for pallet holder on the assembly line, since the assemblers perform the pickings in the order they feel better, moreover, physical boundaries, along with the need to bring closer the parts to the usage location. This process makes that there are many parts of different models, different sizes and characteristics on the same shelf, including hindering the best use of physical space.

In Kitting section, the system is also pick-to-part, but done as addressing system in ascending order of leasing parts, following the flow as follows:

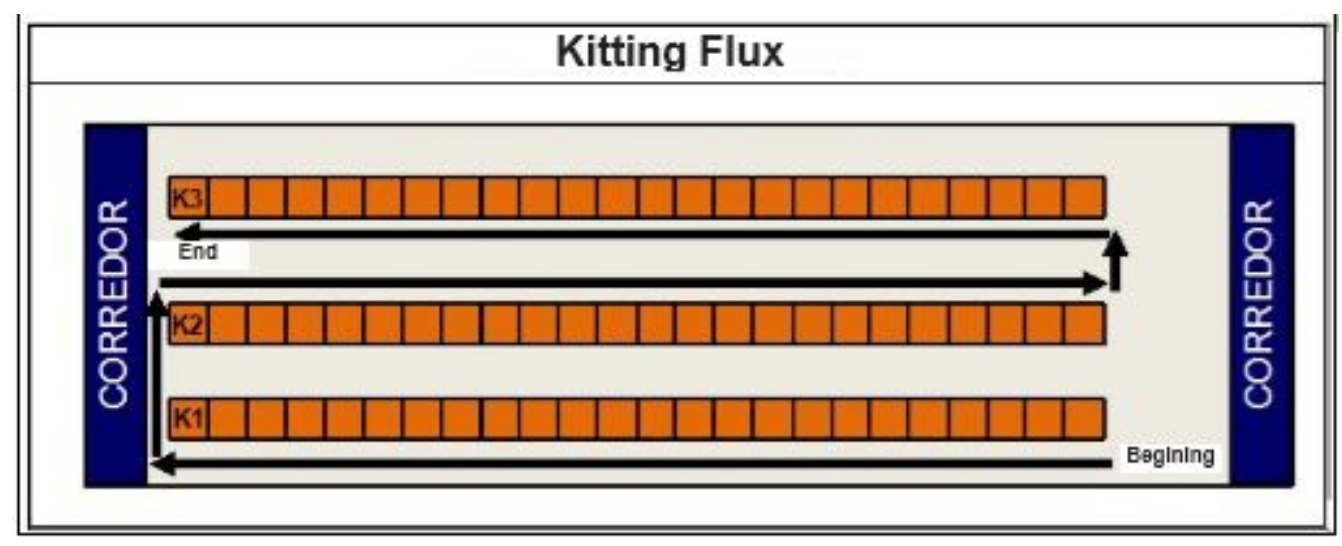

Figure 4: Kitting section parts separation Flow.

The section's work is the semi-indirect type and its efficiency is not controlled

\section{DIAGNOSIS}

Through the Integrated Management System "Hyperion Workspace", software used at the assembly plant, it was observed the current efficiency of Assembly Line (F50) through the history of the last three months: 


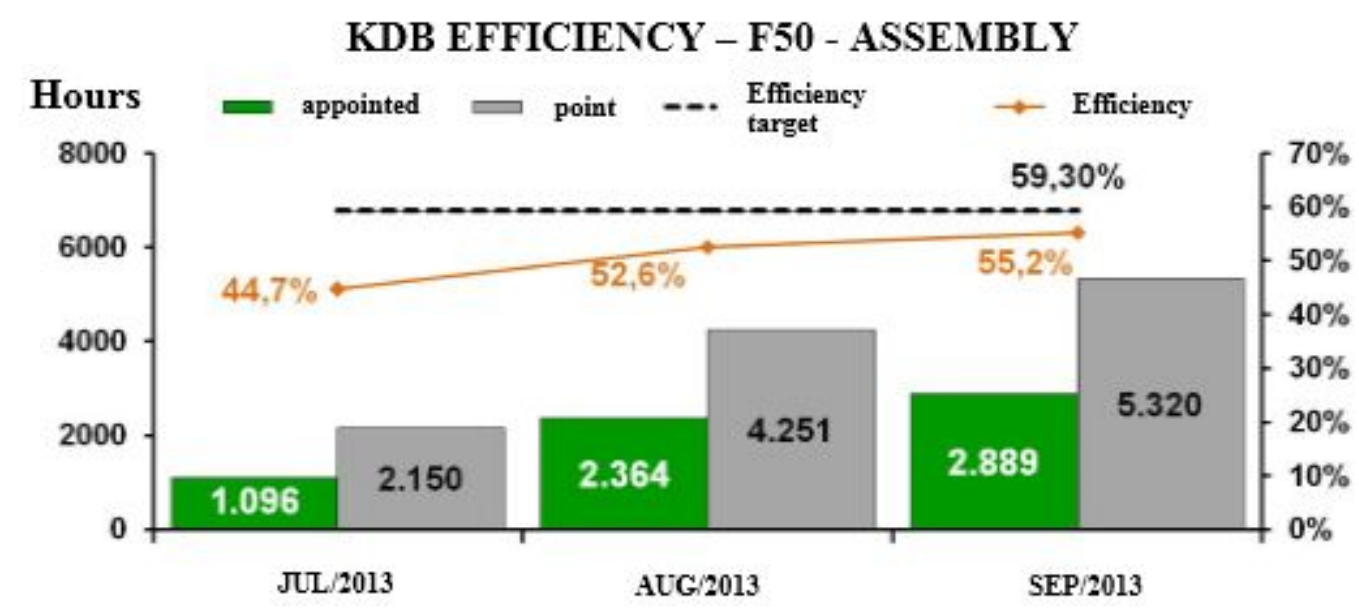

Figure 5: productive efficiency graph in the assembly section Source: Hyperion Workspace - 12.15.2013

Through cronoanalysis, the assembly process was characterized in two parts: The first of the activities that add value to the assembly, and the second of activities that do not add value to the assembly (abnormal).

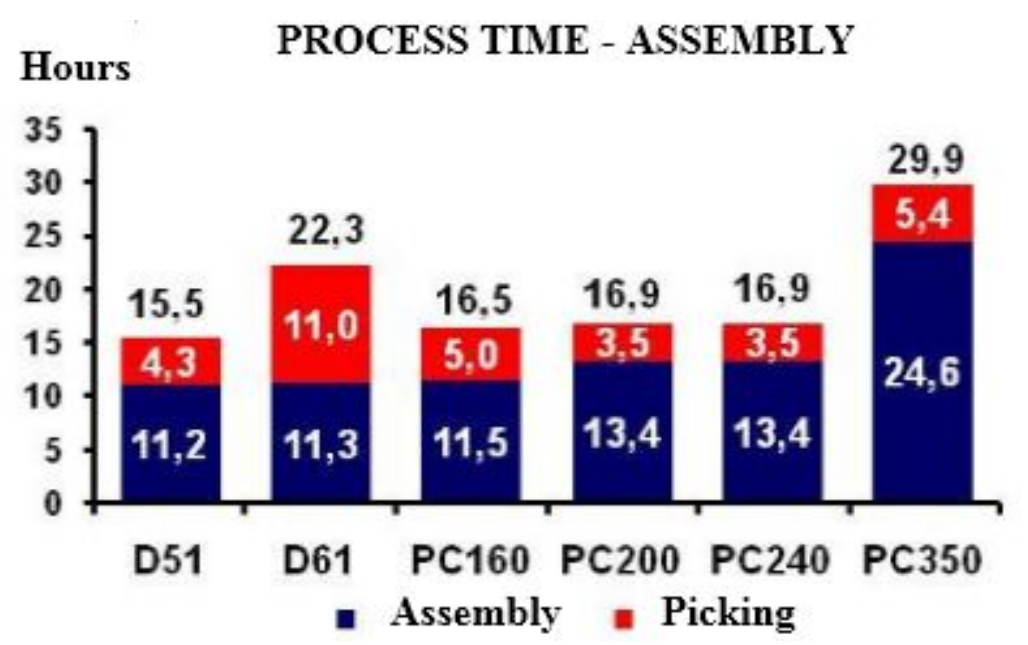

Figure 6: assembly process time graph $\mathrm{x}$ type of activity

Activities, that add value to the assembly, make reference to increase the capacity and efficiency of the productive section, which is the actual assembly line. In this way we can reduce the time on activities that add value to assembly, with investment in new technologies and more productive tools, but cannot eliminate work steps.

Now, the activities that do not add value to the assembly process, are characterized by resolution of defects, overproduction, waiting handling, extra processing, under-utilization of people and especially transportation. To identify the 
DOI: $10.14807 /$ ijmp.v7i5.453

possible causes of the problem of the activities that do not add value, it was performed an Ishikawa diagram, where he highlighted three items: unpacking operations, several machine models in just a shelf and transporting and handling.

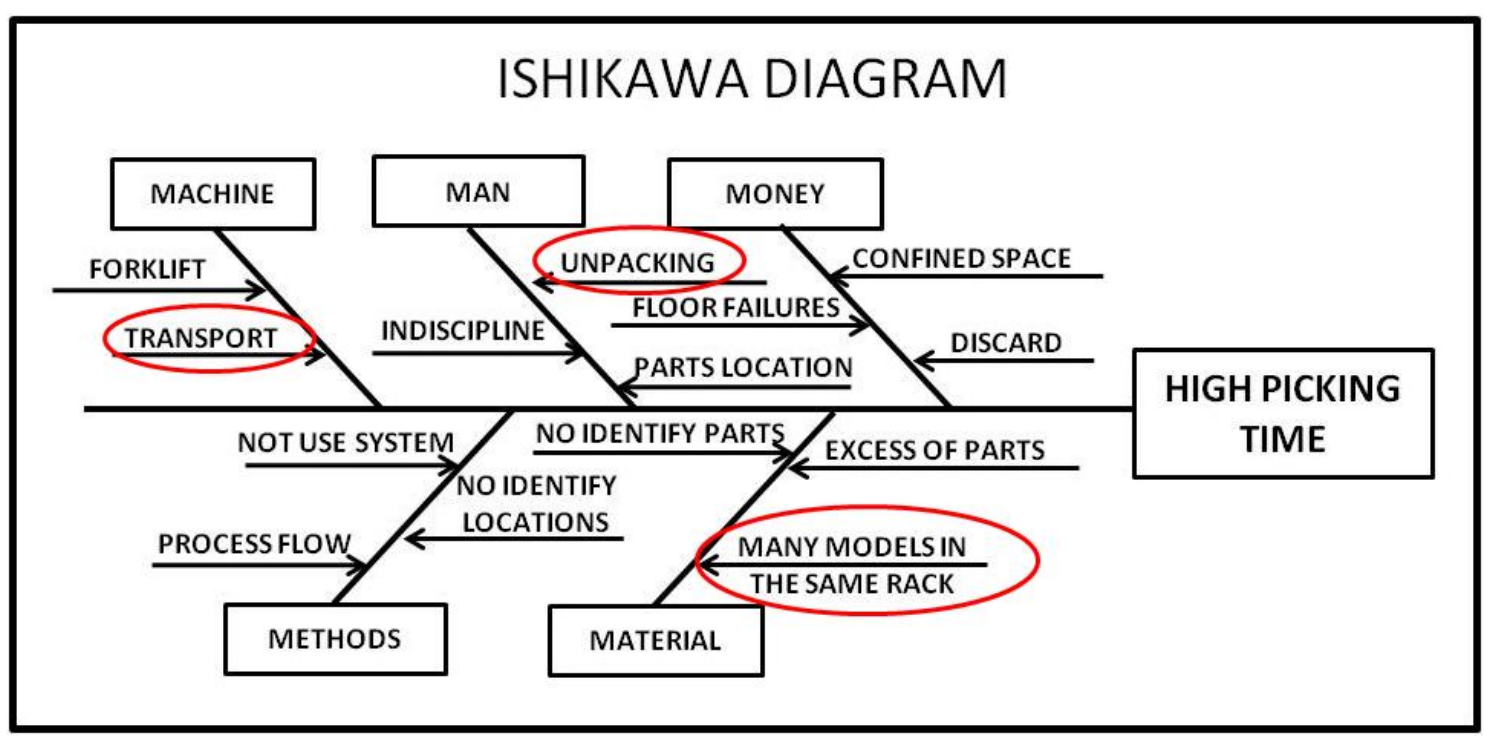

Figure 7: Ishikawa Diagram of activities that do not add value to the assembly.

It was stratified the possible causes of activities that do not add value to the process through the data collected in cronoanalysis, where it was observed that $55 \%$ of these activities were characterized by transport and handling and unpacking $35 \%$ and $10 \%$ others as graph below:

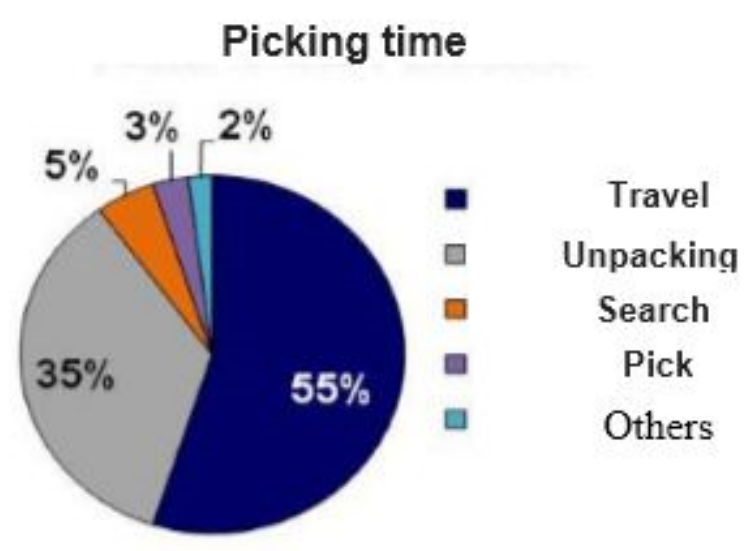

Figure 8: activities that do not add value in the Assembly Line (NVA).

It was analyzed the changes performed on the Assembly Line related to the pick-to-part, where it was found the following flow: 
DOI: 10.14807/ijmp.v7i5.453

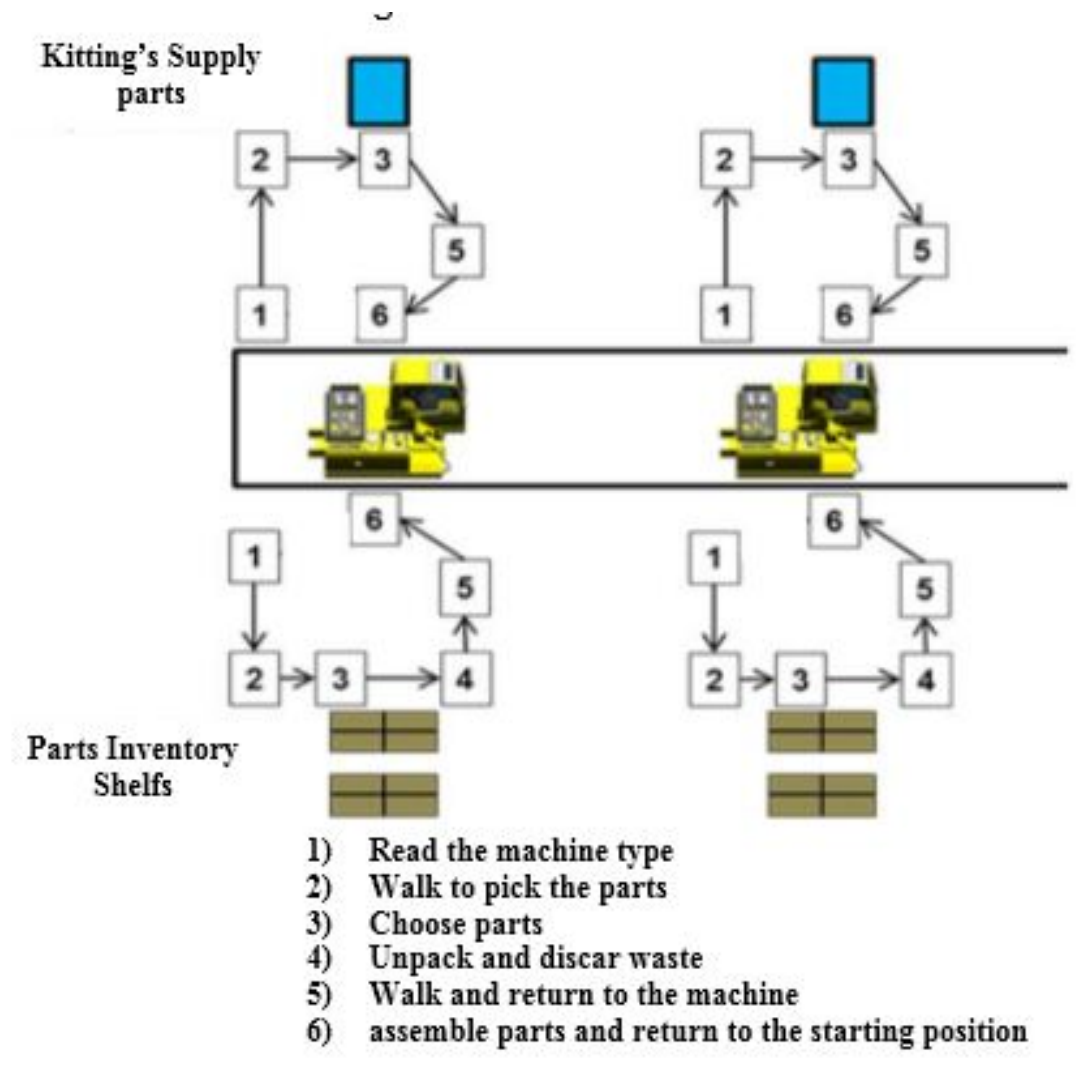

Figure 9: Assembly Process Flow

Through the process flow analysis it can be seen that the handling during the assembly process is very intense, and is difficult to measure exact distances, since the Assembly Line is the continuous pulled type. In that way, the proposal is to reduce the changes to get parts on the shelves and parts from the Kitting section, eliminate unpacking and disposal of the assembly process.

The Kitting process flow is defined by addressing sequence, but the addressing is defined only by the availability of physical space in stock, so that the movements may be higher in most consuming items, as follows: 
INDEPENDENT JOURNAL OF MANAGEMENT \& PRODUCTION (IJM\&P)

http://www.ijmp.jor.br

v. 7, n. 5, Special Edition IFLOG 2015

ISSN: 2236-269X

DOI: 10.14807/ijmp.v7i5.453

TABLE 3: Example of monthly consumption of parts list and addressing.

\begin{tabular}{|c|c|c||}
\hline PART & LOCATION & NONTHL Y CONSUMPTION \\
\hline 1342711310 & 2 K101A2 & 454 \\
\hline 0102480616 & 2 K102C3 & 1257 \\
\hline 0102480818 & 2 K113A5 & 1312 \\
\hline 1246232510 & 2 K116D4 & 227 \\
\hline 0102480820 & 2 K125E1 & 1816 \\
\hline 0102480825 & 2 K202B7 & 978 \\
\hline 0102480620 & 2 K218A3 & 728 \\
\hline 1243030158 & 2 K227B3 & 771 \\
\hline 0102481025 & 2 K317B2 & 908 \\
\hline 1246232580 & 2 K317D3 & 227 \\
\hline 0102481230 & 2 K318B1 & 1816 \\
\hline 0102480630 & 2 K324D1 & 584 \\
\hline \hline
\end{tabular}

This table shows that in many cases the parts consumption is large and the distance to be covered during their separation is larger than that in parts with a lower consumption. The proposal is to reduce handling during the picking process as suggested by Ramos (2010).

\section{RESULTS}

As proposed in the reference, it was created a single location for all parts that reaches the plant, enabling them to be delivered and it was created standardized way to delivery items to assembly line. In the new method of delivering parts, the parts are allocated in a car named Kit machine as delivery addressing (model, serial number and line on), where is supplied the required amount to assemble a machine.

According to the machine production schedule, Kit machine is positioned and pulled few meter away from the machine, as shown below:

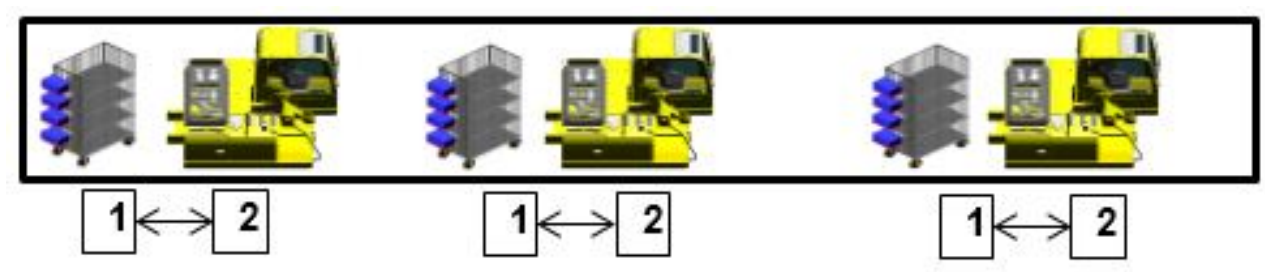

1) Choose parts

2) Assemble parts.

Figure 10: Assembly Process Current Flow.

With the new flow in the assembly line, the assembler does not make handling to the shelf to remove parts, and also does not perform the parts unpacking. After 
DOI: 10.14807/ijmp.v7i5.453

executing the activities, measurement and assembly section efficiency results monitoring was performed, as the graph below:

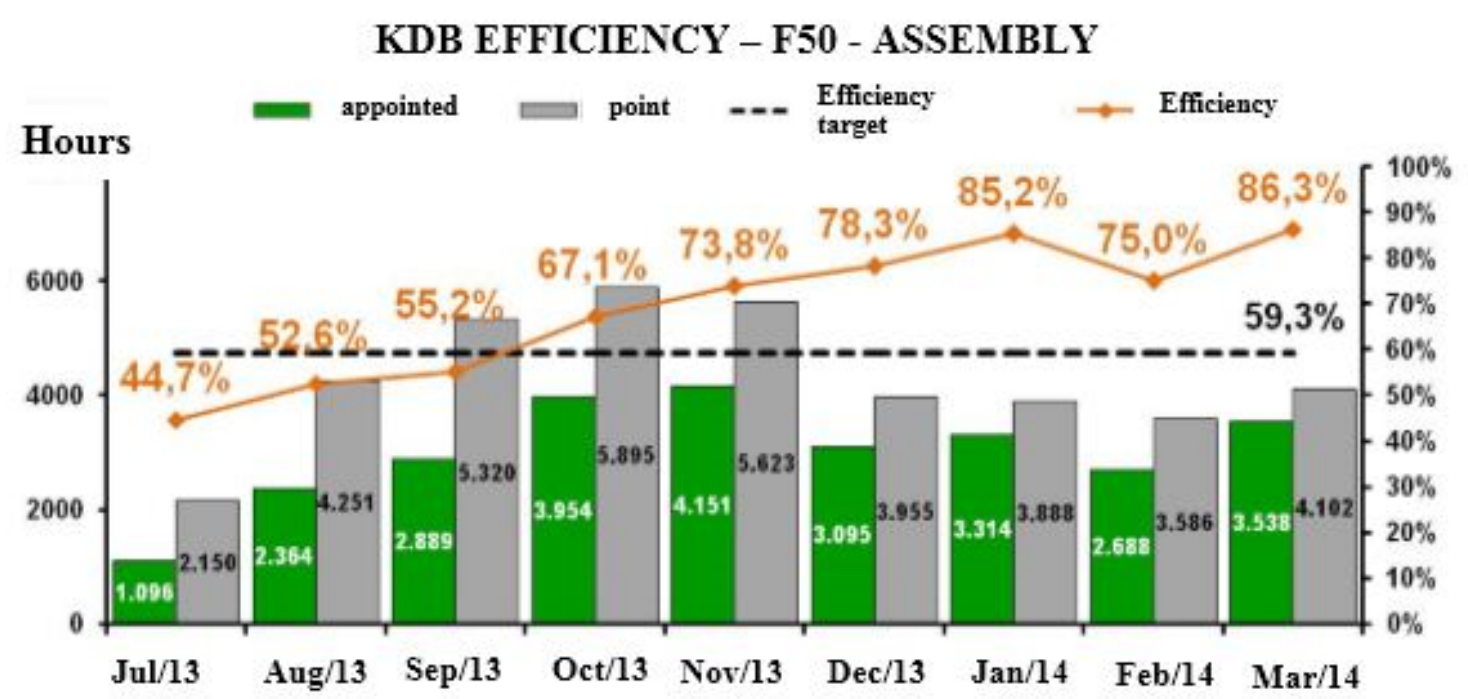

Figure 11: Production efficiency in the assembly industry Source: Hyperion Workspace 01.03.2015

As noted in graph 4, after the implementation of new parts supply flow, and consecutively with a significant reduction of activities that do not add value to the assembly process, there was a significant increase in the efficiency of the assembly line section (F50).

The efficiency loss in February 2014 is acceptable since at this month there was the implementation of a new machine model in the industry, which can also reveal that in this particular case, the assemblers adaptation curve. For the new model. obtained a significant improvement, as previously entailed about four months of falling efficiency. With the new process flow, when occurs a development, the most significant impact is applied to Kitting section, which in these cases, they should prepare spaces and create new picking sequences.

It has expanded the Kitting section to aggregate the parts that were housed in the pallets holder at assembly line. For a leaner picking, it was made up the reorganization of the parts allocation, in accordance with criteria as shown below:

Table 4: Classification of parts

\begin{tabular}{|c|c|c|}
\hline CORRIDOR & CLASSIFICATION & AVERAGE MOVEMENTS /MONTH \\
\hline K1 & HIGH MOVEMENT PARTS & $>1.000$ \\
\hline K2 & MEDIUM MOVEMENT PARTS & $501 \mathrm{~A} 1.000$ \\
\hline K3 & LOW MOVEMENT PARTS & $<500$ \\
\hline
\end{tabular}


INDEPENDENT JOURNAL OF MANAGEMENT \& PRODUCTION (IJM\&P)

http://www.ijmp.jor.br

v. 7, n. 5, Special Edition IFLOG 2015

ISSN: 2236-269X

DOI: 10.14807/ijmp.v7i5.453

It was raised the history over a period of six months to relate the average item movements / month. Thus the items cited as examples in Table 3, were relocated as shown below:

TABLE 5: New allocation of parts

\begin{tabular}{|c|c|c|c|}
\hline PART & $\begin{array}{c}\text { MONTLY AVERAGE } \\
\text { CONSUMPTION }\end{array}$ & PAST LOCATION & $\begin{array}{c}\text { ACTUAL } \\
\text { LOCATION }\end{array}$ \\
\hline 0102480820 & 1816 & 2K125E1 & 2K102B2 \\
\hline 0102481230 & 1816 & $2 \mathrm{~K} 318 \mathrm{~B} 1$ & 2K106A3 \\
\hline 0102480818 & 1312 & 2K113A5 & 2K107D2 \\
\hline 0102480616 & 1257 & 2K102C3 & 2K107E1 \\
\hline 0102480825 & 978 & 2K202B7 & 2K201B1 \\
\hline 0102481025 & 908 & 2K317B2 & 2K202C4 \\
\hline 1243030158 & 771 & 2K227B3 & 2K207B1 \\
\hline 0102480620 & 728 & 2K218A3 & 2K211B3 \\
\hline 0102480630 & 584 & 2K101A2 & 2K213A5 \\
\hline 1342711310 & 454 & 2K116D4 & 2K310C2 \\
\hline 1246232510 & 227 & 2K317D3 & 2K325A4 \\
\hline 1246232580 & 227 & & \\
\hline
\end{tabular}

In this way, the distance traveled by the logistics operators is lower during the picking, improving the process flow and reducing $32 \%$ of the kit's separation average time. The method used for flow rack type shelves in Kitting section, was extended to the pallets holder from the Assembly Line, the final layout of the sections obtained the following organization:

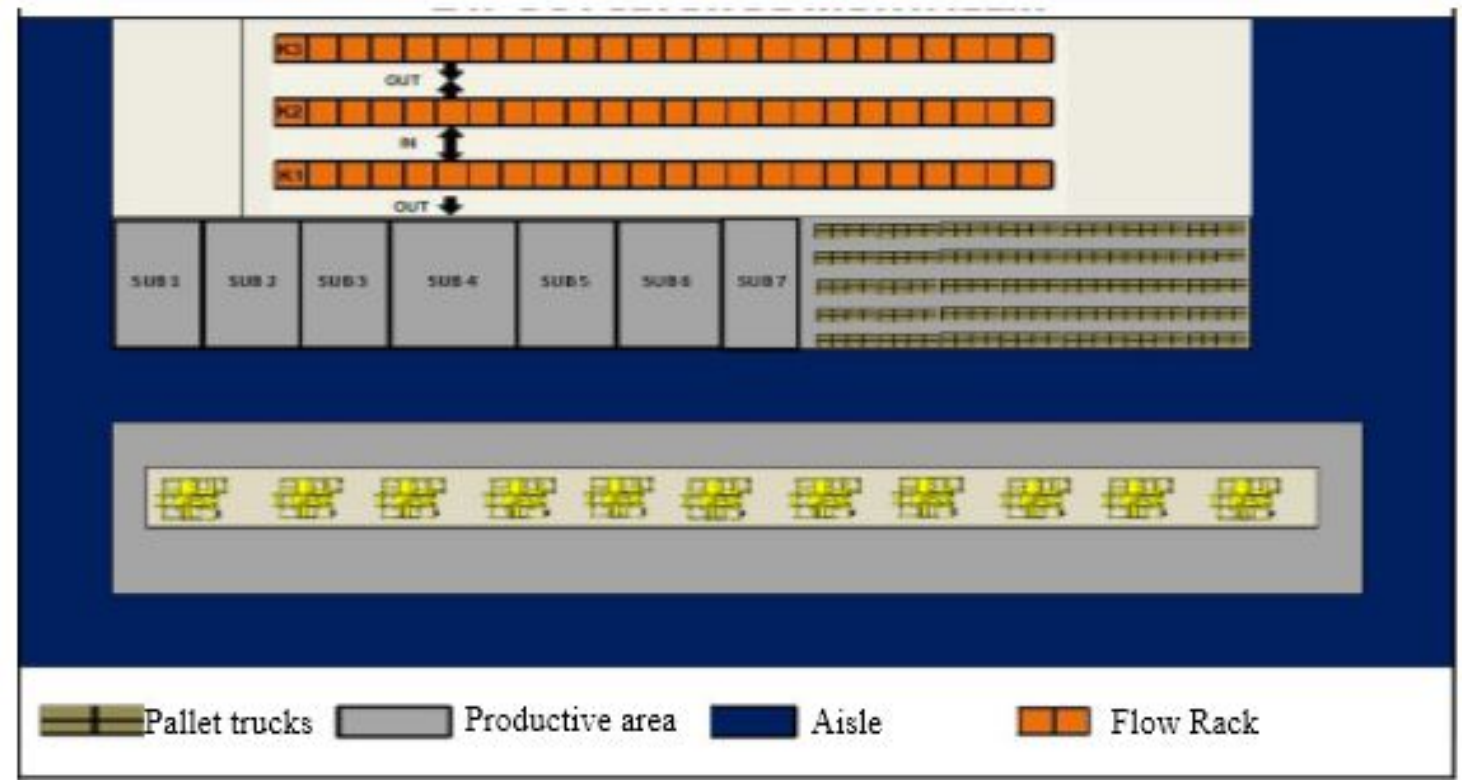

Figure 12: New assembly section layout and Kitting 
INDEPENDENT JOURNAL OF MANAGEMENT \& PRODUCTION (IJM\&P)

http://www.ijmp.jor.br

v. 7, n. 5, Special Edition IFLOG 2015

ISSN: 2236-269X

DOI: 10.14807/ijmp.v7i5.453

According to the new arrangement of the Assembly Line, it was obtained some improvements in processes that involves Assembly Line flow, as follows:

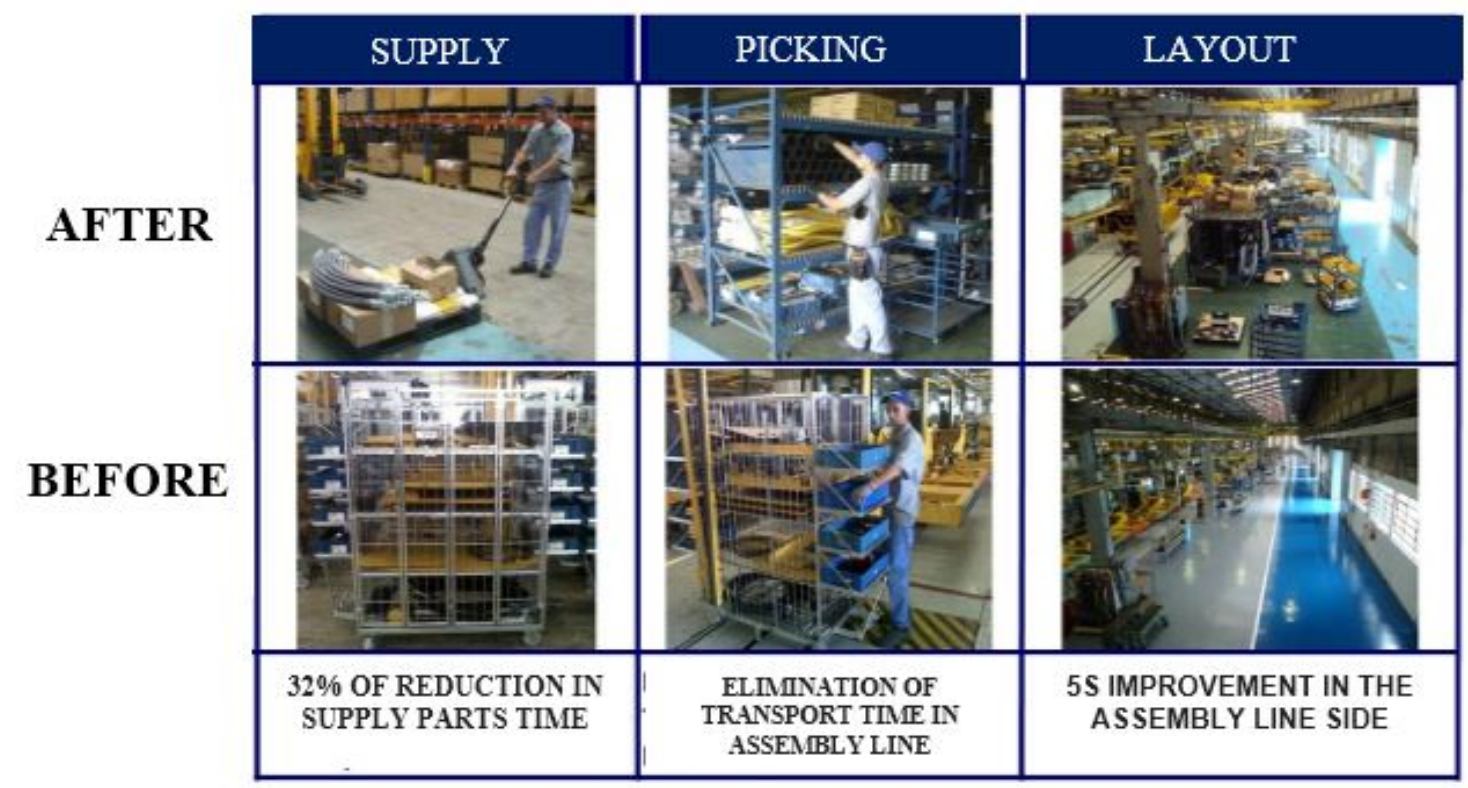

Figure 13: Improvements implemented in Assembly Line

The "kit machine" now effects the parts supplies that previously were made by hydraulic pallet trucks, with the amount depending on the receiving. It contains all the parts to assembly a machine. However transporting the kit machine is made through an electric tug, where you can transport up to 4 units of the kit machine per trip.

The handling during the picking process done by the assembler in which previously was from $3 \mathrm{~m}$ to $18 \mathrm{~m}$, with the added kit machine on the back side of the machine on Assembly Line, it was increased to a maximum of $1 \mathrm{~m}$, reducing to almost zero the assembler's handling.

In terms of layout, it was obtained great advances in relation to $5 \mathrm{~S}$ and principally the production flexibility, which, currently, with the development of new models, it is possible further adaptation from assemblers for items identification of each model and the increase in the mix of machines produced on one line.

Upon execution of the activities that were proposed, the sections involved had some major changes, as Table 6: 
TABLE 6: Major internal changes.

\begin{tabular}{|c|c|}
\hline NAME & MAJOR INTERNAL CHANGES \\
\hline Receipt & $\begin{array}{c}\text { Receives parts and stocks as existing address, } \\
\text { eliminating packaging and } \\
\text { allocating waste. }\end{array}$ \\
\hline Kitting & $\begin{array}{c}\text { Performs separation of parts with better } \\
\text { handling scripts and positions the box kit in the } \\
\text { car side called kit machine. }\end{array}$ \\
\hline Production Stock & $\begin{array}{c}\text { There is no more stock in the production, } \\
\text { machine kit is pulled continuously along with the } \\
\text { assembly line }\end{array}$ \\
\hline Assembly & $\begin{array}{c}\text { Moving in the assembly line is minimal and } \\
\text { constant and unpacking is no longer executed. }\end{array}$ \\
\hline
\end{tabular}

\section{CONCLUSION}

Some implemented actions reflected significantly on direct results in the assembly section efficiency indicators, while others only have noted on other section indicators. The main benefit of the subject company of this study was the improved production efficiency of an assembly line, as shown in Figure 4, which obtained an increase of $50 \%$ to $85 \%$ of productive efficiency during the period of eight months. Another important issue to be mentioned is related to models flexibility to be produced on the assembly line, since the current flow for any model is the same, that is, when there is the implementation of a new machine model, all the logistical effort is to structure the section where are found the parts in stock and kit machine supply.

Regarding the analysis for routing the Kitting section, there was an average gain of $32 \%$ in the total process time and thus strengthen in terms of availability of skilled labor, the new picking process for the pallets holders that previously were located next to the assembly line, not increasing the total picking time.

This paper aims to identify the influence of implementation of lean internal logistics on the productive efficiency of an assembly line. We observed that as quoted by Tompkins (2010) actually transport offered great influence on activities that did not add value to the process, in this way, with the elimination of losses and with a new flow definition, process became leaner. Another issue to be emphasized is that the parts were stored in a single area where it was improved the usage of physical space and speed process. 
INDEPENDENT JOURNAL OF MANAGEMENT \& PRODUCTION (IJM\&P)

http://www.ijmp.jor.br

v. 7, n. 5, Special Edition IFLOG 2015

ISSN: 2236-269X

DOI: 10.14807/ijmp.v7i5.453

This action-research work has shown that the influence of the implementation of lean internal logistics has brought benefits in all processes involved in the study, but it is worth noting that activities have brought great benefit to the studied company, may or may not bring benefits to other companies. In that way the concepts and activities realized can be study objects in researches.

\section{REFERENCES}

ADES, C. (2011) Investimento no setor de construção civil. Estado de São Paulo, São Paulo.

ASSUNÇÃO, D. S. et al. (2013) Modelo de Gestão KAIZEN e Sua Aplicação no Setor de Fertilizantes. In: 4th International Workshop Advances in Cleaner:" Integrating Cleaner production into Sustainability Strategies. p. 1-7.

BARTHOLDI III, J. J.; HACKMAN, S. T. (2011) Warehouse \& distribution science: release 0.92. Atlanta, GA, The Supply Chain and Logistics Institute, School of Industrial and Systems Engineering, Georgia Institute of Technology.

CARVALHO, José Crespo de. (2010) Logística e Gestão Logística. In Logística e Gestão da Cadeia de Abastecimento. Sílabo.

CORTEZ, P. R. L.; et al. (2010) Análise das relações entre o processo de inovação na engenharia de produto e as ferramentas do WCM: estudo de caso em uma empresa do setor automobilístico. XXX ENGEP-Encontro Nacional de Engenharia de Produção. São Paulo.

LAZARIN, D. F. (2010) Roteamento dinâmico de veículos: análise do impacto em atividades de prestação de serviço.

MEDEIROS, W. J. N. (2012) Abordagem heurística paralelizada para a resolução do problema do roteamento de veículos capacitados com base na estratégia, cluster first route second.

MONTEIRO, M. M. (2012) Pull Flow na Indústria Automóvel

KaizenInstituteConsultantGroup. Tese de Doutorado. Universidade do Porto.

NUNES, F. L.; MENEZES, F. M. (2015) Sistema hyundai de produção e sistema toyota de produção: suas interações e diferenças. Revista Acadêmica São Marcos, v. 4, n. 2, p. 101-120.

PEINADO, J.; GRAEML, A. R. (2007) Administração da produção: operações industriais e de serviços. Curitiba :UnicenP.

PEREIRA, L. G. Simulação estocástica e métodos heurísticos paralelizados para a resolução do problema de roteamento de veículos capacitados com base na estratégia, cluster first route second.

PERGHER, I.; et al. (2011) Discussão teórica sobre o conceito de perdas do Sistema Toyota de Produção: inserindo a lógica do ganho da Teoria das Restrições. Gestão \& Produção, v. 18, n. 4, p. 673-686.

RAMOS, M.; Eidt, A. (2015) A filosofia Kaizen no processo produtivo da empresa Construblocos Scherer. 
RAMOS, T. (2010) Gestão da Armazenagem e dos Stocks na Gestão da Cadeia de Abastecimento. Logística e Gestão da Cadeia de Abastecimento.

SAURIN, T. A.; FERREIRA, C. F. (2008) Avaliação qualitativa da implantação de práticas da produção enxuta: estudo de caso em uma fábrica de máquinas agrícolas. Gestão \& Produção, v. 15, n. 3, p. 449-462.

SHIMOKAWA, K.; FUJIMOTO, T. (2011) O nascimento do Lean. Conversas com TaiichiOhno, EijiToyoda. São Paulo: Leaninstitute Brasil, Bookman.

SILVA, I. B.; et al. (2011) Integrando a promoção das metodologias Lean Manufacturing e Six Sigma na busca de produtividade e qualidade numa empresa fabricante de autopeças. Revista Gestão \& Produção, v. 18, n. 4, p. 687-704.

THIOLLENT, M. (2011) Metodologia da pesquisa-ação. In: Metodologia da pesquisa-ação. Cortez.

TOMPKINS, J. A. et al. (2010) Facilities planning. John Wiley \& Sons.

TORRES JR., A. S. (2010) Metadecisão no modelo de gestão Toyotista. Revista de Administração Mackenzie, v. 11, n. 6. 